\title{
The Limits of Monetary Coordination As Exchange Rate Policy
}

PROPOSALS FOR COORDINATION of monetary policy to stabilize nominal or real exchange rates or for targeting monetary policy on the nominal exchange rate assume, explicitly or implicitly, that exchange rate fluctuations are, on balance, harmful to the world economy and that monetary policy can productively reduce the amplitude of these fluctuations. The objective of this paper is to examine the analytical basis and empirical evidence for these assumptions. The conclusion is that both hold only some of the time. A coordination agreement would therefore have to define the circumstances under which the assumptions hold, a difficult task indeed. A third assumption in current proposals for a formal international conference to implement a coordination agreement-a "new Bretton Woods" - is that such an agreement is at least politically feasible. This assumption too is questionable. Toward the end of the paper I will argue that any international conference held now would resemble the failed World Economic Conference of 1933 far more closely than it would Bretton Woods.

Movements in the real exchange rate of the dollar have had substantial effects on employment and output in U.S. manufacturing industries. The elasticity of employment to an appreciation in the real dollar exchange rate is -0.14 . Thus a real 60 percent appreciation of the dollar from 1980 to 1985 would, in itself, have reduced manufacturing employment by 8.4 percent, or 1.7 million jobs. However, even this magnitude of job loss is not a net loss to the economy, because the real dollar appreciation was part of an equilibrium reaction to the shift in the structural budget position in the early 1980s. The real appreciation 
facilitated the foreign financing of a significant fraction of the U.S. fiscal deficit and domestic investment, an effect that would have to be set off against the employment effect in assessing the overall cost or benefit of the dollar appreciation.

Movements in the real exchange rate can have their sources in real disturbances, such as a fiscal shift or an oil price change, or in financial or monetary disturbances that move the nominal exchange rate relative to goods prices. Monetary coordination can limit undesirable fluctuations in real exchange rates coming from the latter, but not the former, type of disturbance.

An example of the limited effectiveness of monetary coordination is provided by the appreciation of the dollar in real terms from 1981 to 1984. The real appreciation was in large part an equilibrium reaction to the fiscal shift that began in 1982 and was achieved mainly via a nominal appreciation (see figure 1), as U.S. goods prices moved roughly in line with foreign prices. A monetary policy that attempted to hold the nominal exchange rate against this pressure would have required a substantially higher growth of money-essentially monetizing the shift in the deficit. The result would presumably have been higher inflation in the United States and a real dollar appreciation through inflation instead of the nominal exchange rate. In this case it seems preferable to achieve the real appreciation by permitting the nominal rate to move.

The difficulty of taking equilibrium movements of real exchange rates into account in an agreement on monetary coordination is compounded by the fact that there is no analytical consensus on the causes of fluctuations in the equilibrium real exchange rate. For example, the relationship of the post-1981 shift in the U.S. structural fiscal deficit to the real appreciation of the dollar is a matter of dispute. My analysis below follows a crowding-out line that requires the trade balance to do its share to make room in full-employment gross national product for the shift in the budget. This position is attacked from one side by Keynesians who argue that the real appreciation was due to tight money and from the other side by monetarists who argue that there is no relationship between shifts in the budget position and the real exchange rate. With this range of disagreement on economic analysis, how are the negotiators to reach agreement? The topic is one for the National Science Foundation, not a new Bretton Woods.

The main part of this paper provides the evidence and analysis that 
Figure 1. Nominal and Real Effective Dollar Exchange Rates, 1979:1-1985:4a

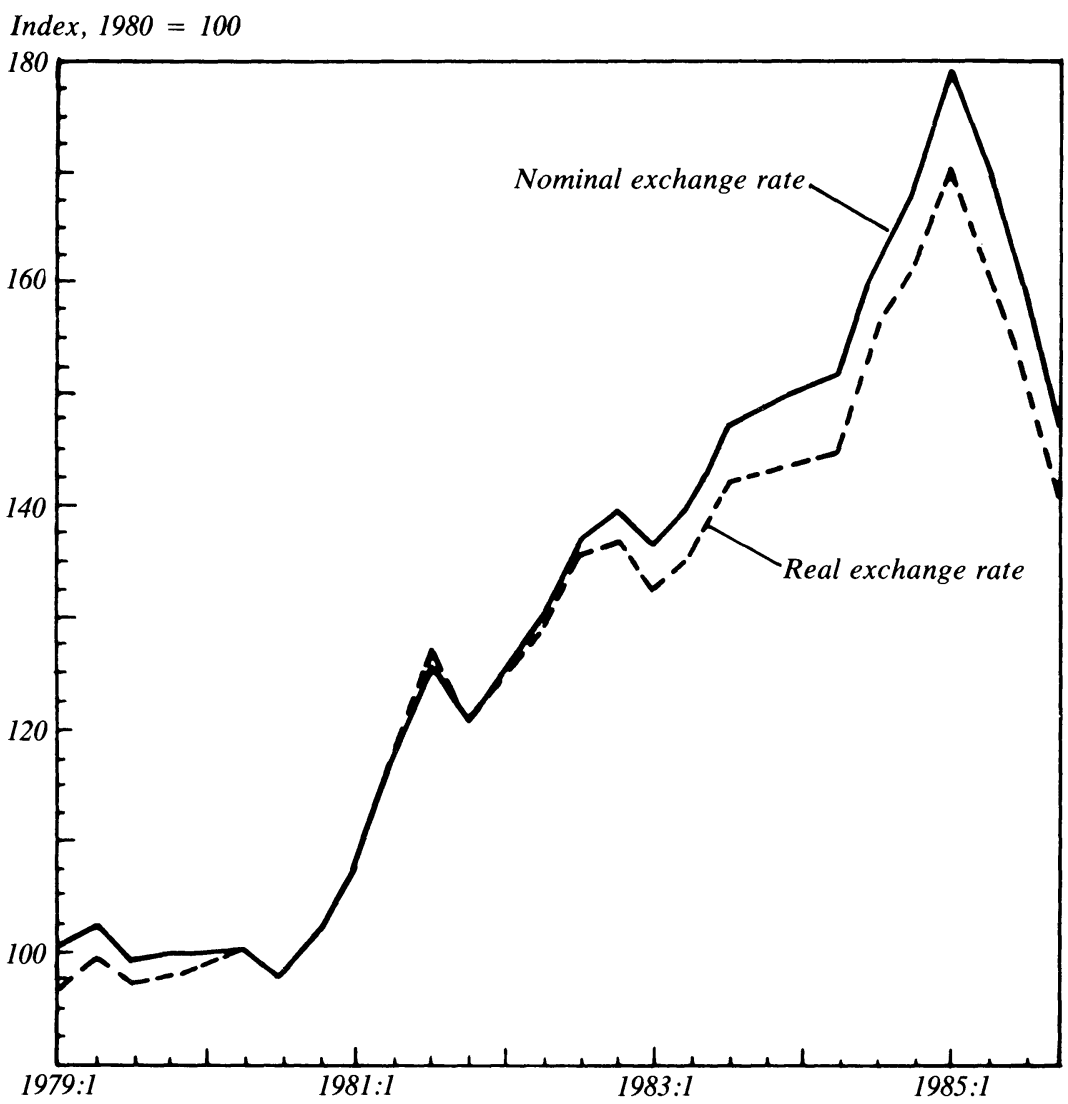

Sources: Author's calculations, based on data from Economic Report of the President, February 1986, table B-105, and earlier issues.

a. Quarterly data. The nominal exchange rate is based on the Federal Reserve series for the weighted average nominal exchange value of the U.S. dollar against the currencies of the Group of Ten industrial countries. Real rate is adjusted for changes in the consumer price index. A rise in either index is an appreciation of the dollar against foreign currencies.

support the argument just presented. First, I estimate the effects of fluctuation in the real exchange rate of the dollar on U.S. nonagricultural employment and summarize the relation of movements in nominal and real exchange rates. Then I present the analysis of the effect of a shift in the fiscal deficit on the equilibrium real exchange rate. Finally, I explore the analog between the "new Bretton Woods" and 1933. 


\section{The Real Exchange Rate and Employment}

In a recent paper coauthored with James P. Love, I report results from an empirical study of the effects of fluctuations in the dollar's real exchange rate on employment and output in manufacturing industries in the United States. ${ }^{1}$ These effects are presumably a major source of unhappiness with the movement of the dollar, concern about its "misalignment," and pressure to stabilize it. The employment findings are summarized by industry and by state in the appendix. Here I show the results for all nonagricultural employment.

The estimates of an equation explaining fluctuations in nonagricultural employment from 1963 to 1985 are shown in table 1. The real exchange rate coefficients in the table show the elasticity of employment by sector to movements in the real exchange rate. Employment in the mining sector is most responsive to movements in the dollar, with an elasticity of -0.387 . Durable manufacturing is second, with an elasticity of -0.206 . All manufacturing has a highly significant elasticity of -0.140 , mentioned earlier. Transportation and public utilities, wholesale and retail trade, finance and real estate, and service all have insignificant coefficients. Government employment shows a significant elasticity of -0.165 , a decrease in government employment coinciding with the appreciation of the dollar.

The results in the Branson and Love study, summarized here and in the appendix, are consistent with the hypothesis that fluctuations in the real exchange rate have serious effects on employment in manufacturing, particularly on the durable goods producers.

\section{Real and Nominal Exchange Rates}

With nominal exchange rates moving flexibly relative to sluggish goods prices, movements in the real exchange rate are dominated by movements in the nominal rate. Jacob Frenkel has documented this relationship for the 1970s; evidence for the U.S. dollar between 1979

1. William H. Branson and James P. Love, "The Real Exchange Rate and Employment and Output in U.S. Manufacturing 1974-85"' (Princeton University, March 1986). 


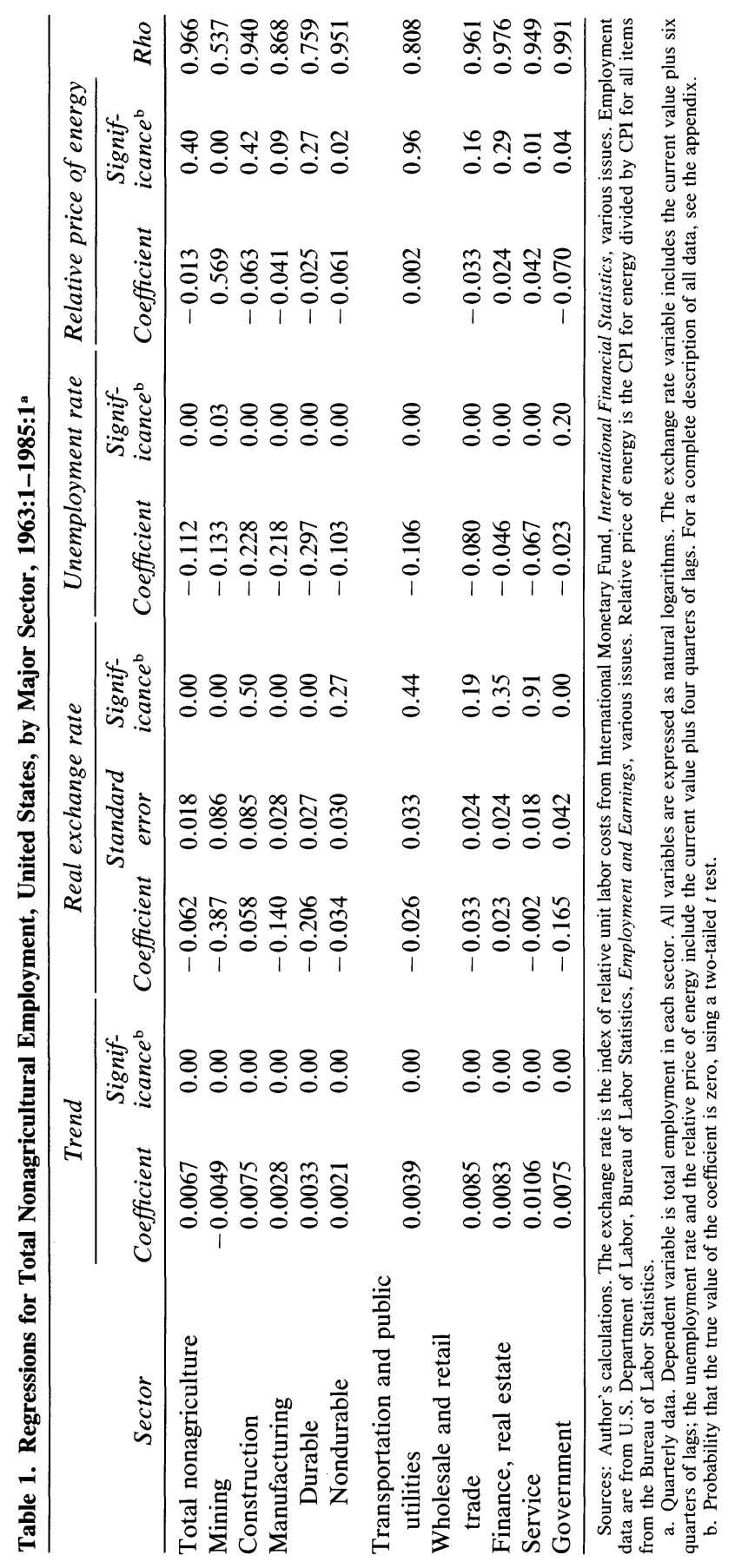


and 1985 is summarized in figure 1 , which shows the nominal and real effective rates calculated by the Federal Reserve Board. ${ }^{2}$ The correlation between the two effective rates from 1979 through 1985 is clear.

The point of the evidence in figure 1 is that movements in the nominal exchange rate may have been reactions to equilibrium adjustments in real rates. In this case, a monetary intervention that attempted to stabilize the nominal rate would frustrate the movement of the real rate in the short run and shift the adjustment to relative prices in the longer run. This is one way in which a monetary policy that stabilized the nominal exchange rate would be counterproductive. I now turn to the analysis that indicates that the swing in the real exchange rate of the dollar in the 1980 s was precisely such an equilibrium reaction.

\section{Fiscal Policy and the Real Exchange Rate}

To establish the relationship between real disturbances and equilibrium adjustment of the real exchange rate, in this section I summarize a short-run "fundamentals" model of fiscal policy and the real exchange rate. ${ }^{3}$ The model is a framework for analysis that integrates goods markets and asset markets to describe simultaneous determination of the interest rate and the exchange rate. It is a short-run model in the sense that the existing stock of assets is taken as given; it is a fundamentals model because it focuses on the underlying macroeconomic determinants of movements in rates, about which the market will form expectations. The framework is useful because it makes it possible to distinguish between such external events as shifts in the budget position (the deficit), shifts in international asset demands (the safe haven effect), and changes in tax law or financial regulation on the basis of their differing implications for movements in the interest rate and the exchange rate. I begin with

2. Jacob A. Frenkel, "Flexible Exchange Rates, Prices, and the Role of 'News': Lessons from the 1970's," Journal of Political Economy, vol. 89 (August 1981), pp. 665705.

3. The model is laid out in detail in William H. Branson, "Causes of Appreciation and Volatility of the Dollar," in Federal Reserve Bank of Kansas City, The U.S. DollarRecent Developments, Outlook, and Policy Options (FRBKC, 1985), pp. 33-52. The rational expectations extension is in William H. Branson, Arminio Fraga, and Robert A. Johnson, "Expected Fiscal Policy and the Recession of 1982," Working Paper 1784 (National Bureau of Economic Research, December 1985). 
the national income, or flow-of-funds, identity that constrains flows in the economy, then turn to asset-market equilibrium that constrains rates of return, and finally bring the two together in figure 2 .

The national income identity is generally written as

$$
Y=C+I+G+X=C+S+T,
$$

where $Y=$ gross national product

$C=$ consumer expenditure

$I=$ gross private domestic investment

$G=$ government purchases of goods and services

$X=$ net exports of goods and services, or the current account balance

$S=$ gross private domestic saving

$T=\operatorname{tax}$ revenue.

All flows are in real terms. Subtracting consumer expenditure, $C$, from both sides of the right-hand equality and rearranging to obtain a useful version of the flow-of-funds identity yields:

$$
G-T=(S-I)-X .
$$

In terms of national income and product flows, equation 1 says the combined federal, state, and local government deficit must equal the sum of the excess of domestic private saving over investment less net exports.

Thinking of equation 1 as holding at a standardized full-employment level of output excludes cyclical effects from the discussion and focuses on shifts in the budget at a given level of national income. If a shift in the full-employment fiscal deficit, $G-T$, is taken as external, or exogenous to the economy, equation 1 emphasizes that this shift requires some endogenous adjustment to excess private saving, $(S-I)$, and the current account, $X$, to balance the flows in income and product. In particular, if $G-T$ is increased $\$ 200$ billion, roughly the actual annual increase in the structural deficit, a combination of an increase in $(S-I)$ and a decrease in $X$ that also totals $\$ 200$ billion is required.

According to standard macroeconomic theory, at a given level of national income, $(S-I)$ depends positively on the real interest rate, $r$, 
Figure 2. Financial Market Equilibrium

Real domestic interest rate

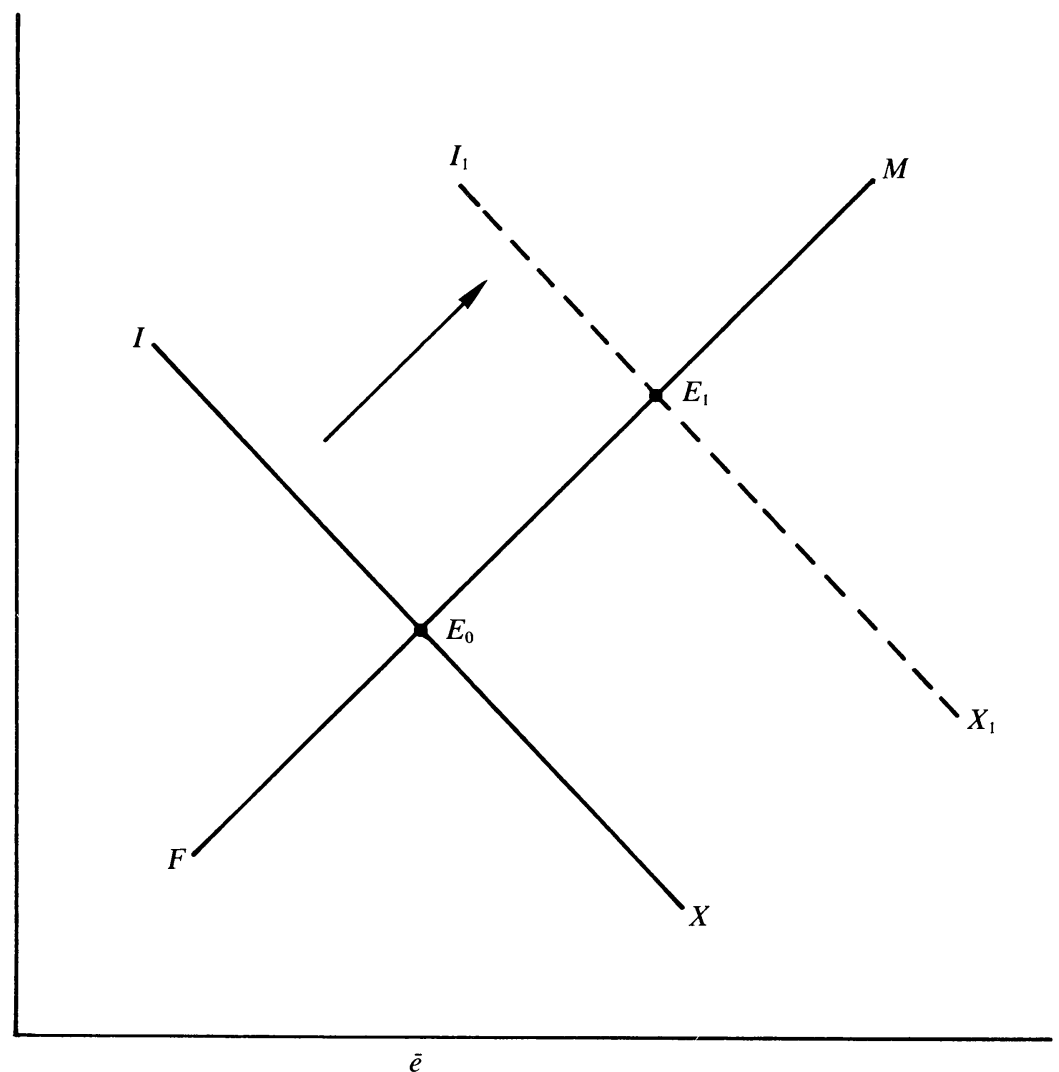

Real exchange rate

and $X$ depends positively on the real exchange rate, $e$ (units of foreign exchange per dollar adjusted for relative price levels). So the endogenous adjustments that would increase $(S-I)$ and reduce $X$ are increases in $r$ and $e$. Some combination of these changes would restore balance in equation 1 , given an increase in $G-T$.

This national income view of the adjustment mechanism can be expressed in terms of foreign borrowing and capital flows by noting that net exports, $X$, are net foreign investment (from the balance of payments 
identity). Since national net foreign investment is minus national net foreign borrowing, $N F B$, equation 1 can also be written as

$$
G-T=(S-I)+N F B .
$$

This form of the identity emphasizes that an increase in the deficit must be financed either by an increase in the excess of domestic saving or by an increase in net foreign borrowing (decrease in net foreign investment).

The actual movements in the deficit, domestic saving, and net foreign investment, and the associated movements in the real short-term interest rate and the real exchange rate are shown in table 2 . The combined federal, state, and local government deficit was slightly over $\$ 14$ billion at the beginning of 1981 . It expanded to a peak of $\$ 167$ billion in the bottom of the recession in the fourth quarter of 1982, and then shrank during the recovery. But the shift in the federal budget position left the total government deficit at over $\$ 150$ billion in mid-1985, after two years of recovery. Initially the deficit was financed mainly by net domestic saving, which also peaked at the bottom of the recession. But since 1982 the fraction financed by net foreign borrowing has risen; by mid-1985 most of the government deficit was financed by foreign borrowing.

The movements in the real interest rate and the real exchange rate roughly reflect this pattern of financing. The real interest rate jumped from negative values in 1979 to more than 6 percent in 1982, then fluctuated around 5 percent until early 1985. The real exchange rate jumped sharply from late 1980 to mid-1982, then rose more gradually through mid-1984 before accelerating to its peak in 1985. The standard lags in adjustment of net exports to changes in the exchange rate can explain the slow reaction of net exports, or net foreign borrowing, to the dollar appreciation.

The relationship between the real interest rate, $r$, and the real exchange rate, $e$, that is imposed by financial market equilibrium can be seen by considering the returns that a representative U.S. asset holder obtains on domestic and foreign assets of the same maturity. The return on the domestic asset is $i$ in nominal terms and $r=i-\hat{P}$ in real terms, where $\hat{P}$ is the exogenous expected rate of inflation. The nominal foreign interest rate is $i^{*}$, and the return on the foreign asset is $i^{*}-\hat{e}$ in nominal terms, where $\hat{e}$ is the expected rate of change in the exchange rate. In real terms the U.S. asset holder's return would be $i^{*}-\hat{e}-\hat{P}$. In equilibrium, the difference between the two returns must be equal to the 
Table 2. Saving and Investment Flows, Interest Rates, and Exchange Rates, United States, 1979:1-1985:4

Billions of dollars unless otherwise specified

\begin{tabular}{|c|c|c|c|c|c|c|}
\hline Period & $\begin{array}{l}\text { Net foreign } \\
\text { investment }\end{array}$ & $\begin{array}{c}\text { Excess } \\
\text { domestic } \\
\text { savings }^{\mathrm{b}}\end{array}$ & $\begin{array}{l}\text { Total } \\
\text { budget } \\
\text { deficit }^{c}\end{array}$ & $\begin{array}{l}\text { Federal } \\
\text { deficit } \\
\text { (percent } \\
\text { of GNP) }\end{array}$ & 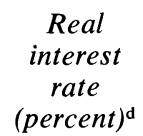 & $\begin{array}{c}\text { Real } \\
\text { exchange } \\
\text { rate index } \\
(1980=100)^{\mathrm{e}}\end{array}$ \\
\hline 1979:1 & 6.9 & -6.2 & 20.7 & 0.4 & -1.0 & 93.4 \\
\hline $1979: 2$ & -0.8 & -15.8 & -18.5 & 0.2 & -4.3 & 97.7 \\
\hline 1979:3 & 5.7 & -8.5 & -8.1 & 0.8 & -3.7 & 96.7 \\
\hline 1979:4 & -1.5 & -5.9 & 1.5 & 1.1 & -1.5 & 99.7 \\
\hline 1980:1 & 1.4 & -2.8 & 12.1 & 1.4 & -3.4 & 101.4 \\
\hline 1980:2 & 13.4 & 48.0 & 41.9 & 2.4 & -4.6 & 101.7 \\
\hline $1980: 3$ & 29.2 & 74.6 & 48.6 & 2.7 & 1.5 & 97.7 \\
\hline 1980:4 & 8.0 & 45.8 & 35.5 & 2.4 & 1.8 & 99.1 \\
\hline 1981:1 & 17.4 & 23.3 & 14.6 & 1.6 & 3.0 & 103.6 \\
\hline 1981:2 & 6.0 & 15.5 & 14.8 & 1.7 & 6.3 & 111.0 \\
\hline 1981:3 & 6.6 & 28.4 & 26.2 & 2.0 & 3.4 & 117.5 \\
\hline 1981:4 & 12.3 & 72.9 & 63.1 & 3.1 & 5.1 & 115.1 \\
\hline 1982:1 & 7.3 & 88.1 & 76.0 & 3.5 & 9.1 & 119.8 \\
\hline 1982:2 & 16.5 & 93.3 & 77.7 & 3.6 & 7.0 & 124.5 \\
\hline 1982:3 & -12.3 & 113.5 & 122.5 & 5.0 & 2.0 & 127.7 \\
\hline 1982:4 & -15.4 & 144.6 & 166.8 & 6.3 & 6.4 & 128.5 \\
\hline 1983:1 & 3.6 & 155.0 & 150.0 & 5.8 & 7.8 & 124.1 \\
\hline 1983:2 & -28.2 & 91.3 & 123.8 & 5.1 & 4.1 & 125.2 \\
\hline 1983:3 & -47.0 & 84.3 & 127.0 & 5.2 & 4.9 & 126.6 \\
\hline 1983:4 & -59.0 & 64.4 & 122.3 & 5.1 & 4.6 & 129.0 \\
\hline 1984:1 & -65.5 & 25.5 & 93.8 & 4.3 & 4.1 & 130.4 \\
\hline 1984:2 & -93.9 & 5.3 & 97.3 & 4.4 & 6.2 & 131.6 \\
\hline 1984:3 & -94.3 & 20.9 & 116.0 & 4.7 & 6.5 & 139.4 \\
\hline $1984: 4$ & -110.4 & 24.1 & 126.9 & 5.0 & 5.1 & 144.7 \\
\hline 1985:1 & -76.8 & 20.1 & 99.4 & 4.2 & 5.0 & 152.4 \\
\hline 1985:2 & -105.8 & 50.8 & 151.9 & 5.3 & 3.4 & 146.1 \\
\hline 1985:3 & -126.2 & 15.7 & 144.5 & 5.0 & 4.6 & 137.5 \\
\hline $1985: 4$ & -152.5 & 13.5 & 168.0 & 5.6 & 2.9 & 127.3 \\
\hline
\end{tabular}

Sources: U.S. Department of Commerce, Bureau of Economic Analysis, The National Income and Product Accounts of the United States, 1929-1982 Statistical Tables, table 5.1 (Government Printing Office, forthcoming); Survey of Current Business, vol. 66 (March 1986); International Monetary Fund, International Financial Statistics, various issues; and data from the Board of Governors of the Federal Reserve System and the U.S. Department of Labor, Bureau of Labor Statistics.

a. Net foreign investment in the national income accounts summed with the national capital grants received by the United States.

b. Gross private domestic saving minus gross private domestic investment.

c. Combined federal, state, and local budget deficit.

d. Three-month Treasury bill rate minus the change in the consumer price index.

e. Index of relative unit labor costs computed by the IMF. 
market-determined risk premium, $\rho(B)$, where $\rho$ is the risk premium on dollar-denominated bonds and $B$ is the outstanding stock of government debts. Here it is assumed that dollar-denominated bonds are imperfect substitutes for foreign-exchange-denominated bonds, so that the risk premium on dollar bonds increases with their supply: $\rho^{\prime}(B)>0$. The equilibrium condition for rates of return in real terms is then

$$
r-\left(i^{*}-\hat{e}-\hat{P}\right)=\rho(B) .
$$

Next, the expected rate of change of the exchange rate is related to the actual current rate. If the perceived long-run equilibrium real rate that sets the full-employment current account balance at zero is denoted as $\bar{e}$, one reasonable assumption is that the current rate is expected to return gradually toward long-run equilibrium. This assumption can be written as a proportional adjustment mechanism:

$$
\hat{e}=\theta(\bar{e}-e) .
$$

If $\bar{e}$ is below the long-run equilibrium, it is expected to rise, and vice versa. Putting equation 4 into the equilibrium condition, equation 3 , and rearranging a bit, yields the financial-market relationship between $e$ and $r$ :

$$
e=\bar{e}+\frac{1}{\theta}\left[r-\left(i^{*}-\hat{P}\right)-\rho(B)\right] .
$$

This condition says that for given values of the bond stock, $B$, inflation, $\hat{P}$, the foreign nominal interest rate, $i^{*}$, and the long-run equilibrium real exchange rate, $\bar{e}$, an increase in $r$ requires a rise in $e$ to maintain equilibrium in financial markets. Why? If the home interest rate rises, equilibrium can be maintained for a given foreign rate only if the exchange rate is expected to fall. From equation 4, the actual current rate must rise to establish $\hat{e}<0$. In terms of market operations, the rise in domestic interest rates, $r$, causes sales of foreign assets and exchange rate appreciation until equilibrium is reestablished. This is essentially what happened in 1981 with the announcement of a path of future U.S. deficits. The expected deficit path did not substantially change the long-run $\bar{e}$ that would balance the current account, but it did move $r$ and $e$.

The flow equilibrium condition, equation 1 , and the rate-of-return condition, equation 5 , can be joined to form the short-run framework for 
simultaneous determination of $r$ and $e$. Rewriting equation 1 to show the dependence of $S$ and $I$ on $r$ and of $X$ on $e$ gives:

$$
G-T=S(r)-I(r)-X(e) .
$$

For a given level of the full-employment budget, the trade-off between $r$ and $e$ that maintains flow equilibrium is given by the negatively sloped $I X$ curve in figure 2. For a given $G-T$, an increase in $r$, which reduces $(S-I)$, requires a decrease in $e$, which increases $X$, to maintain flow equilibrium. An increase in $G-T$ will shift the $I X$ curve up or to the right, requiring some combination of a rise in $r$ and $e$ to maintain flow equilibrium.

The rate-of-return condition, equation 5 , gives the positively sloped $F M$ curve in figure 2 , for given $B, i^{*}, \hat{P}$, and $\bar{e}$. Its slope is $\theta$, the speedof-adjustment parameter for expectations. An increase in the risk premium, $\rho$, due to a rise in the supply of U.S. bonds, $B$, will shift the $F M$ curve up and to the left, requiring an increase in $r$ for any given value of $e$.

In the short run, equilibrium $r$ and $e$ are reached at the intersection of $I X$ and $F M$ in figure 2; there, both equilibrium conditions are met. For the purposes of the analysis here, the assumption is that initially $e=\bar{e}$, with no expected movement in exchange rates. This is taken to represent the equilibrium around 1980, before the surge in interest rates and the exchange rate in question.

A shift in the full-employment, or structural, budget toward deficit shifts the $I X$ curve up, as shown by the dashed $I X$ curve in figure 2 . The real interest rate and the real exchange rate rise, as described earlier. The composition of these movements is determined by the slope of the $F M$ curve, representing financial market equilibrium. The movement of $r$ and $e$ from $E_{0}$ to $E_{1}$ raises excess domestic saving, $(S-I)$, and reduces net exports, $X$, by a sum equal to the shift in $G-T$. This also produces the short-run equilibrium financing of the shift in the deficit by domestic saving and foreign investment. The results of the shift in $G-T$ are the movements in excess domestic saving and foreign investment and in $r$ and $e$ that are shown in table 2. Thus the framework of figure 2 roughly captures the movements of $r$ and $e$ from 1981 to 1985.

The object of this section is to show that a shift in fiscal policy, much as occurred beginning in 1982, will generate an equilibrium adjustment in the real exchange rate as part of the financing process. This movement 
is probably being reversed now, as the Gramm-Rudman legislation brings real interest rates and the exchange rate down. A monetary policy that attempted to frustrate this movement probably would be a mistake now, as it would have been in 1982. It would not productively reduce the fluctuations in the nominal exchange rate.

Any agreement on coordination of monetary policy or on targeting monetary policy on the nominal exchange rate would have to allow for the effects of real disturbances such as shifts in fiscal policy on the equilibrium real exchange rate. The analysis here places the responsibility for the real appreciation of the dollar squarely on the shift in fiscal policy. However, as noted, there is currently no consensus on the analysis of these effects.

In fact, the level of disagreement on the analysis makes a meaningful formal agreement on monetary coordination virtually impossible. A loose form of central bank coordination may be useful to smooth out the volatility of exchange rates. But coordination on targeting is not going to eliminate the broad swings in equilibrium real rates that have been labeled "misalignment," and should not be attempted.

\section{A New Bretton Woods?}

The 1944 Bretton Woods conference essentially ratified a United States-United Kingdom agreement on monetary coordination. Its 44 signatories met in a context of analytical consensus and agreement on the need to stabilize exchange rates to prevent a repetition of the competitive devaluations of the 1930s. No such consensus about analysis or objectives exists today, and a conference would have twice as many members. There would be a larger number of significant economic actors and a seeming infinity of potential blocking coalitions.

A better model for a new monetary conference might be the World Economic Conference of 1933, in which objectives were in conflict and the analytical understanding of the relationship between exchange stabilization and national objectives was at best limited. That conference failed because of a conflict between American and European objectives, as summarized by Kenneth A. Oye:

At the Conference, Roosevelt considered a joint French and British proposal for temporary currency stabilization, and instructed the American delegation to 
seek agreement on ever higher dollar/sterling rates. When one of the American offers was accepted, Roosevelt simply withdrew the offer.

Why did the United States reject the joint proposal? The concessions offered were simply not commensurate with the concession sought, a currency stabilization that Roosevelt believed would vitiate domestic reflation. In fact, rumors of the impending stabilization agreement had triggered a sharp decline in stock and commodity prices. This may have reinforced Roosevelt's views on the desirability of further dollar depreciation. ${ }^{4}$

A similar absence of analytical consensus and conflict of economic interests makes a major monetary conference now a likely failure. Let the central banks do the coordination and the National Science Foundations of the world finance research on the analysis.

\section{APPENDIX}

\section{Estimates of the Sensitivity of Employment to the Real Exchange Rate}

INITIAL RESULTS from an empirical investigation of the relationship between movements in the real exchange rate and employment and output for U.S. manufacturing industries are reported in a recent working paper that I coauthored with James P. Love. ${ }^{5}$ Here I summarize the employment results by industry and by state. In this research, we have not modeled each industry or state individually, taking into account the special demand shocks and price effects that may be important. Rather, we have constructed general reduced-form models that apply to each disaggregated sector or state.

The dependent variable in the regressions is the natural logarithm of total employment. The independent variables include a constant, the natural logarithm of an index to measure the real U.S. trade-weighted exchange rate, and three variables to capture secular and cyclical changes in demand: time, the natural logarithm of an index to measure the real

4. Kenneth A. Oye, "The Sterling-Dollar-Franc Triangle: Monetary Diplomacy 192937," World Politics, vol. 38 (October 1985), p. 186.

5. Branson and Love, "The Real Exchange Rate." 
price of energy, and the natural logarithm of the overall unemployment rate. We considered the inclusion of a foreign demand variable, but found that deviations from trend growth in foreign demand were so highly correlated with changes in U.S. demand that no additional explanatory power came from foreign demand.

The data are quarterly. The equations are estimated from 1963:1 to 1985:1, with in general eighty-nine observations. The exchange rate variable includes the current value plus six quarters of lags. The real energy price and the unemployment rate both include the current value plus four quarters of lags. The estimates employ the Beach-MacKinnon maximum likelihood procedure for correcting first-order autocorrelation. ${ }^{6}$

The source of the data on employment is various issues of the Bureau of Labor Statistics' Employment and Earnings. In the regional equations, we use the number of workers employed in manufacturing industries, disaggregated by the fifty states plus the District of Columbia. In the industry classifications, we use the number of workers employed in each of the twenty industries with two-digit standard industrial classification (SIC) codes. To test how sensitive the estimates are to changes in the level of aggregation we have estimated equations for all 125 of the threedigit manufacturing code industries and all 176 four-digit industries included in the Bureau of Labor Statistics Establishment Survey tape.

The real exchange rate index is the International Monetary Fund's measure of the weighted foreign exchange value of the dollar, adjusted for movements in relative unit labor costs. The measure is reported in the relative cost tables in International Financial Statistics and is taken to represent movement in U.S. costs relative to those of major competitors. An increase in the index represents a real appreciation of the U.S. dollar.

The results are reported by industry in table A-1 and by state in table A-2. The tables report the value of the first-order autocorrelation coefficient, the coefficients for each of the independent variables except for the constant, and a significance statistic. When independent variables are lagged, the coefficient represents the sum of all lagged coefficients.

6. Charles M. Beach and James G. MacKinnon, "A Maximum Likelihood Procedure for Regression with Autocorrelated Errors," Econometrica, vol. 46 (January 1978), pp. $51-58$. 


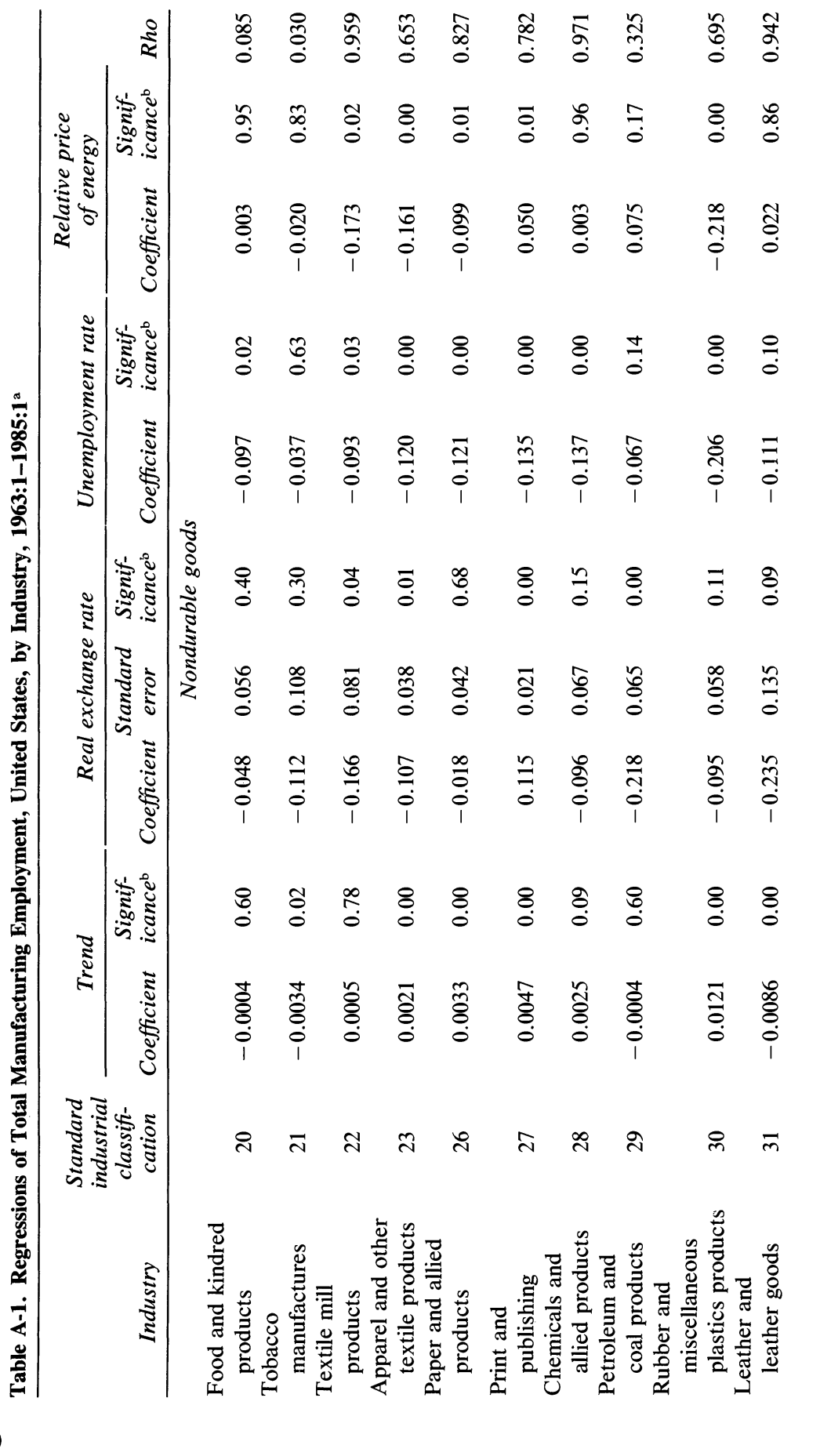




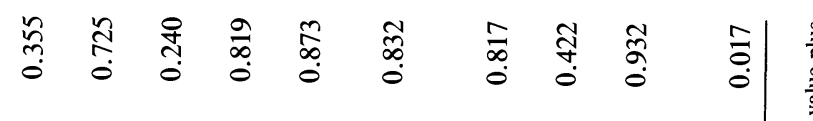

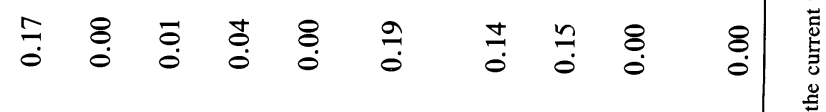

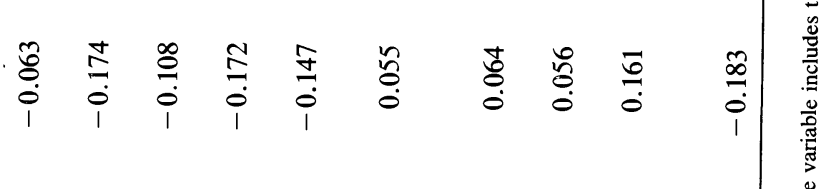

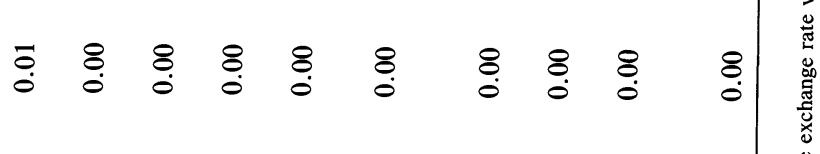

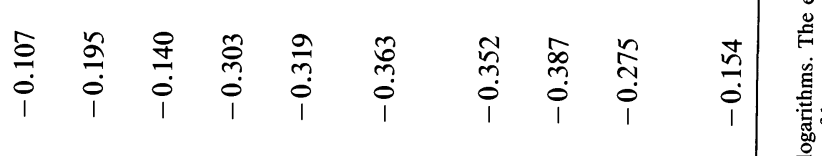

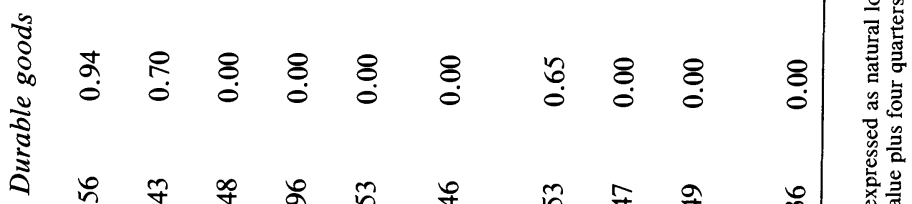

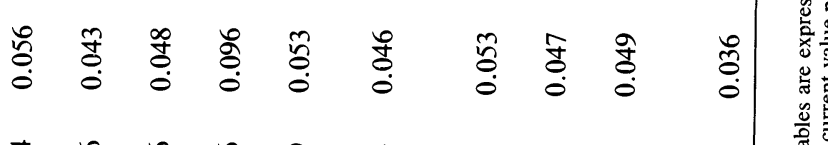

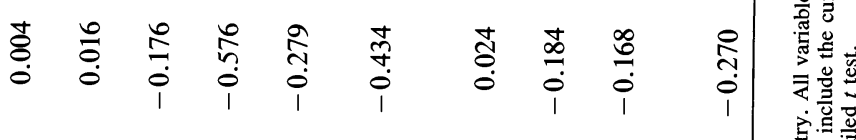

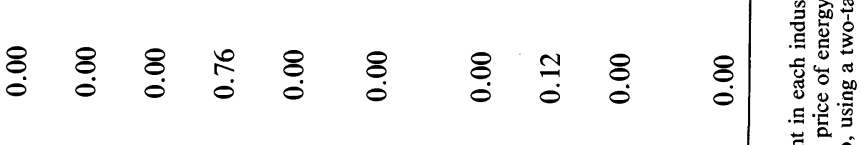

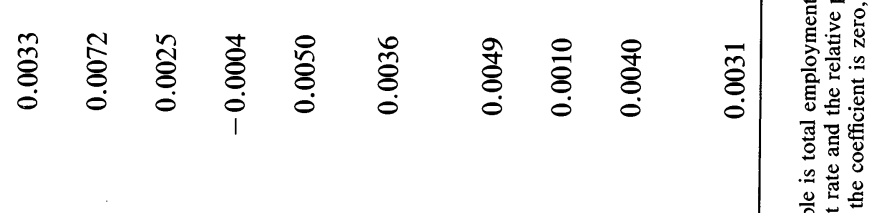

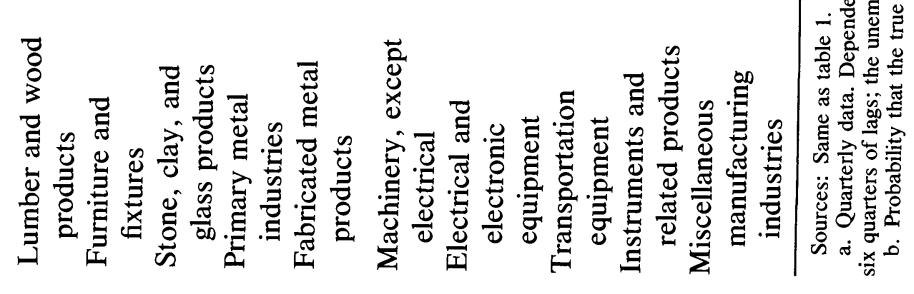




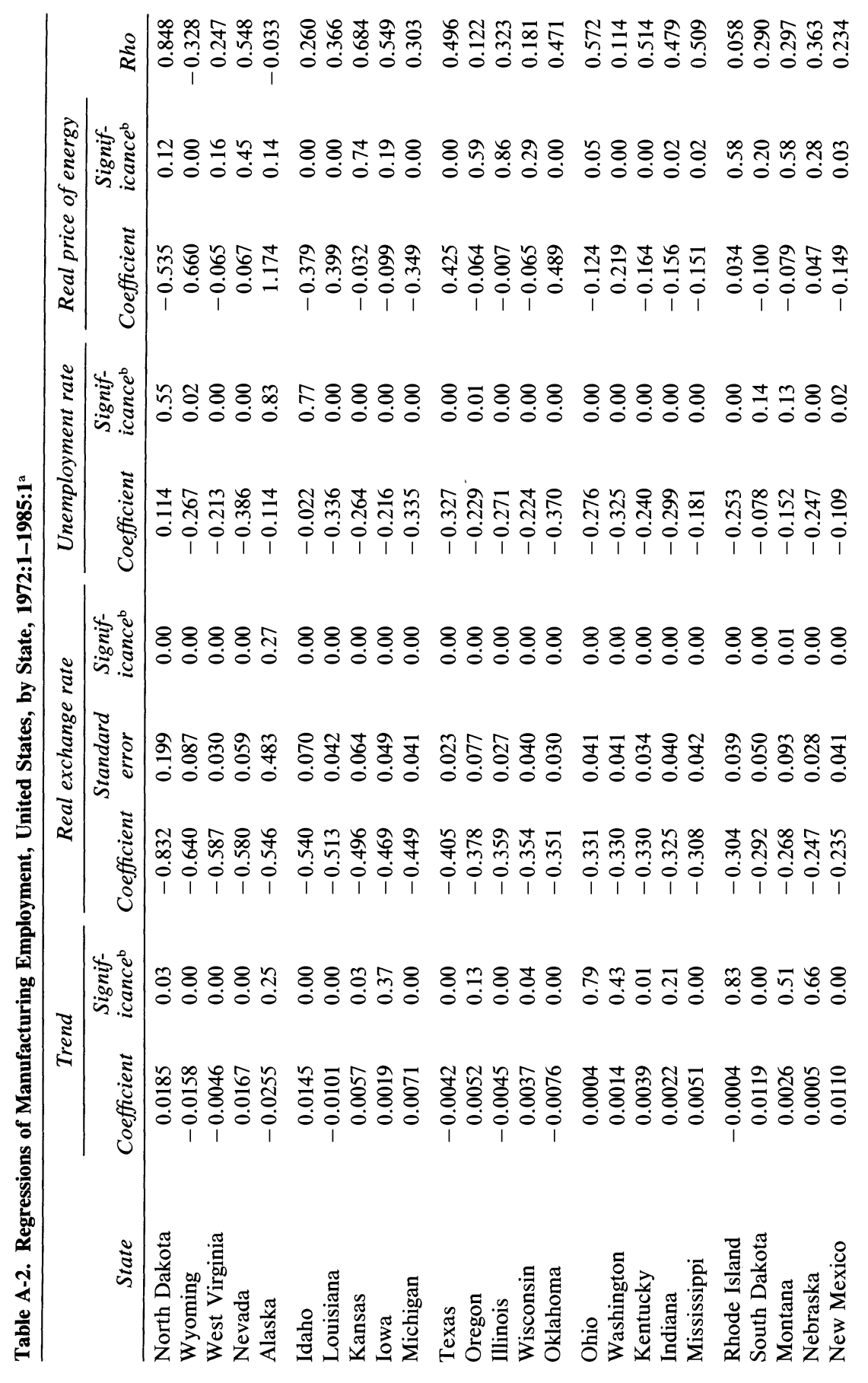




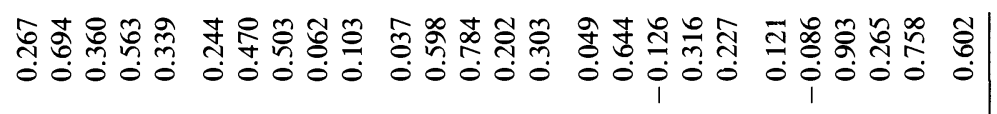

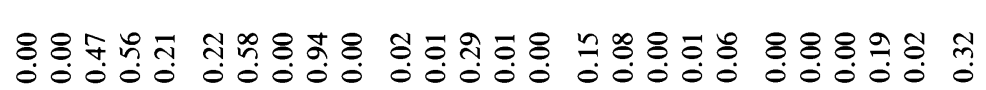

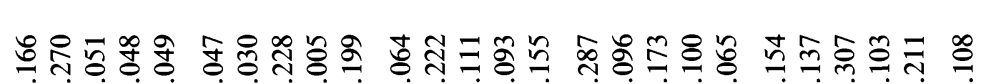

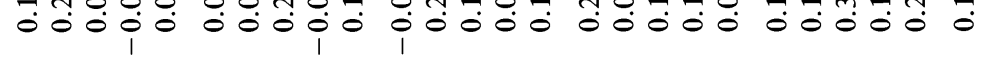

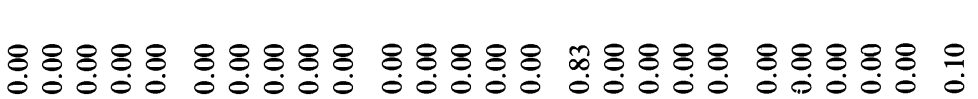

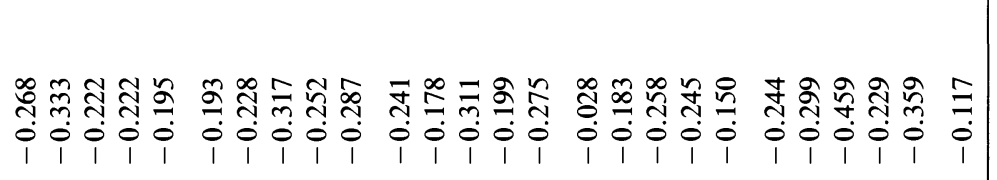

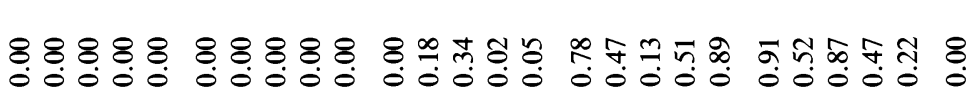

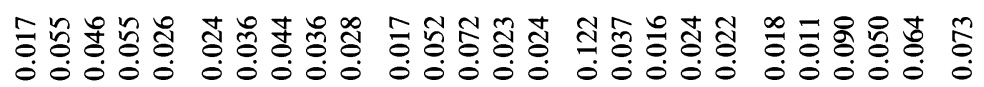

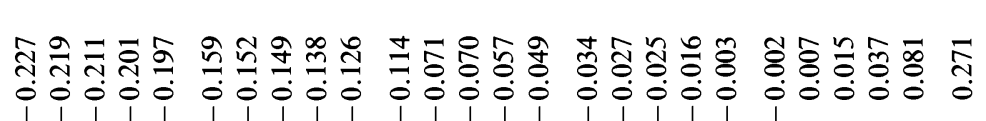

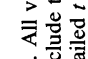

s. 要 施主 进密 虫 这

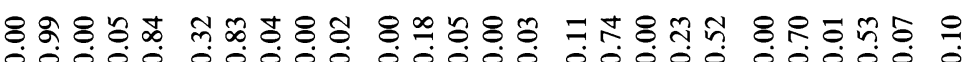

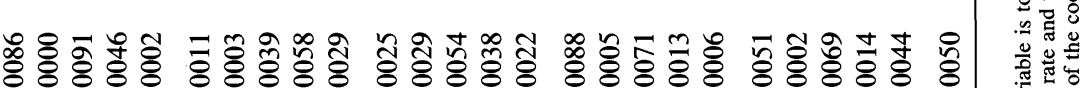

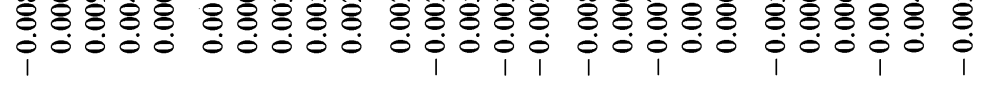

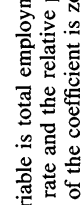

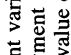

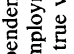

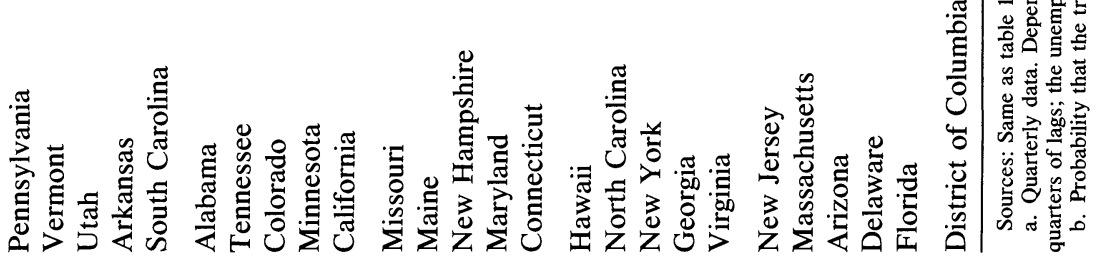


The significance measure is the probability that the true value of the coefficient is zero, using a two-tailed $t$ test. The coefficient for the time variable is the estimated exponential rate of growth or decline in employment (wages or output) that occurs because of secular changes in taste, comparative advantage, or technology. The coefficients on the real exchange rate, the real price of energy, and the employment ratio can be interpreted as elasticities.

In table $A-1$, the coefficient of the real exchange rate variable is negative for sixteen of twenty industries and significant at the 0.05 level for eleven industries. Within the nondurable goods industries, textile mill products, apparel and other textile goods, and petroleum and coal products are negative and significant at the 0.05 level. Somewhat less significant but showing important negative effects are chemicals and allied products, rubber and miscellaneous plastic products, and leather and leather goods. The coefficient for the print and publishing industry is significant and positive.

The durable goods sector has seven industries with a negative coefficient for the real exchange rate that is significant at the 0.01 level, including stone, clay, and glass products, primary metal products, fabricated metal products, nonelectrical machinery, transportation equipment, instruments and related products, and miscellaneous manufacturing. Coefficients for lumber and wood products, furniture and fixtures, and electrical and electronic equipment are positive but small and not statistically significant.

The results by state are shown in table A-2, sorted by the size of the exchange rate coefficient. The coefficient is significant at the 0.01 level for thirty-five states, and at the 0.05 level for thirty-eight states. The sign is negative for forty-six states, including all in which it is significant at the 0.05 level. The elasticity of employment with respect to the real exchange rate in the "Rust Belt" states runs from -0.45 in Michigan to -0.23 in Pennsylvania. There are four states at the bottom of the list with insignificant positive coefficients. The service-oriented District of Columbia has the only significantly positive coefficient. 